\title{
MEMOIRS
}

\section{ROBERT WALLACE STURGEON}

Robert Wallace Sturgeon died on 20 August 1966, aged 77. He became a Fellow of the Institute in 1915, served on the Council for 13 years between 1933 and 1947, and was a Vicc-Prcsident from 1942 to 1946. For 21 years from 1926 he was Actuary of the Royal, and before his retirement in 1952 he was one of three chief executives of the Royal group.

Sturgeon was educated at Liverpool Institute, a school that has made a notable contribution to the actuarial profession, and joined the service of the Royal in Liverpool under D. C. Fraser. When the National Health Insurance scheme was started in 1912, Sturgeon, encouraged no doubt by Fraser, joined the group under A. W. Watson that was later to become the Government Actuary's Department and he remained in Government service until 1924 when he returned to the Royal in anticipation of Fraser's retirement. In 1943 Sturgeon added general management responsibilities to those of Actuary and he relinquished the appointment of Actuary in 1947. When he retired in 1952 he was one of a triumvirate of General Managers which shared the top executive responsibilities of the Royal group and which included C. F. Trustam.

During the 1930s Sturgeon took a leading part on behalf of the British life offices in the negotiations leading to new insurance laws in India. He was appointed by the Indian Government to be a member of the Advisory Committee on Indian insurance legislation, and made two visits to India in the course of this work. In February 1939 he submitted a paper to the Institute, entitled 'The Indian Insurance Act 1938'. From 1942 to 1944 he was Chairman of the Foreign Committee (as it was then called) of the Life Offices' Association, and from 1947 to 1949 Chairman of the Special India and Pakistan Committee of the British Insurance Association.

I have little doubt that Sturgeon found his greatest satisfaction in the 'official' world. He used to speak with nostalgia of his Government service and especially of his work for the Ministry of Shipping during the First World War; he also derived considerable pleasure from his contacts with the Government of India, and with the U.K. Government during the framing of the Assurance Companies Act, 1946, in which he played a part behind the scenes.

Outside his work, too, Sturgeon was an active man, playing football at school and subsequently cricket of a high local standard. In later life he played golf, keenly but not well, and he and his wife specially enjoyed the theatre. He was a Liverpool magistrate for a long period and served on the Council of Liverpool University for 6 years. The last years of his service and the early years of his retirement were clouded by the long disabling illness of his wife who predeceased him. He subsequently remarried, and is survived by his second wife.

J. M. BEATTIE

\section{EWART KINGSLEY READ}

Ewart Kingsley Read died on the 28 March 1967 at the age of 68 . He was born on 29 April 1898, and was educated at Christ's Hospital which he left in 1915, having become a Deputy Grecian for Mathematics. He joined the Legal and General Assurance Society in August 1915 but was hardly settled there before he was called for war service which lasted from 1916 to 1919. He joined the Essex Regiment but later was commissioned and attached to the 16th Argyll and Sutherland Highlanders. 
On his return to Legal and General he resumed his actuarial studies and became a Fellow of the Institute in 1926. He was a tutor in Reversions and Finance from 1935 to 1939 , and an examiner from 1945 to 1950 . For six years from 1950 he served on the Council. In 1961 he submitted a paper to the Institute entitled 'Life Office Property Investments' (J.I.A. 87, 275). His office career was wholly with Legal and General and lasted nearly 47 years. In 1932 he was appointed Assistant Secretary, with special responsibility for reversions and life interests-a subject upon which he became an acknowledged authority. In later years he became Assistant Actuary, Joint Actuary, Life Manager and, in 1952, Assistant General Manager. In the post-war years he was largely instrumental in building up his Society's extensive portfolio of mortgages.

Kingsley Read's outside interests were extraordinarily wide and in no case superficial, for everything he did had to be done thoroughly. In sport he was active in rugger, tennis, badminton, squash and swimming. He was a great churchman, being Deputy Chairman of the Parochial Church Council and a chorister to the last. His interest in music was not confined to the church and he was often to be seen at concerts and at the opera. He was a stern but just critic of the Insurance Orchestral Society, of which he was a Vice-President for many years. Other interests were the theatre and philately. He was the Founder President of the Insurance and Banking Philatelic Society of Great Britain.

Kingsley Read's charitable interests were extensive, but there is no doubt that the dominant interest in these and indeed of his whole life, was his old school, Christ's Hospital. For many years he was a member of the governing body, the Council of Almoners. He was also Treasurer of the Old Blues' Benevolent Fund.

Kingsley did not wear his heart on his sleeve and only the fortunate few who knew him really well realized what a generous heart lay behind what sometimes seemed a sternly formal exterior. His charity was never cold but was always engaged by the human interests involved; nor was it always confined to the deserving-he often helped his frailer brethren to regain their footing. Few men have led a fuller life.

Kingsley Read is survived by his wife to whom he was married in 1924. She shared many of his interests, particularly that in Christ's Hospital.

G. LINGWOOD 